\title{
Effect of city waste compost applied alone and in combination with chemical fertilizer on the yield and nutrient uptake of wheat and subsequent maize crop
}

\author{
Taimur Naseem ${ }^{1 *}$, Maria Mussarat ${ }^{1}$, Muhammad Arshad Khan ${ }^{1}$, \\ Muhammad Waheed ${ }^{1}$, Tariq kamal ${ }^{2}$, Muhammad Adil ${ }^{3}$ and Sher Nawab \\ $\mathrm{Khan}^{4}$ \\ 1. Department of Soil and Environmental Sciences, The University of Agriculture Peshawar, KPK, Pakistan \\ 2. Department of Agricultural Extension Education and Communication, The University of Agriculture Peshawar, \\ KPK, Pakistan. \\ 3. Department of Agronomy, The University of Agriculture Peshawar, KPK, Pakistan \\ 4. Department of Plant Breeding and Genetics, The University of Agriculture Peshawar, KPK, Pakistan \\ *Corresponding author's email: agrian276@gmail.com (00923369180699) \\ Citation \\ Taimur Naseem, Maria Mussarat, Muhammad Arshad Khan, Muhammad Waheed, Tariq kamal, Muhammad Adil \\ and Sher Nawab Khan. Effect of city waste compost applied alone and in combination with chemical fertilizer on \\ the yield and nutrient uptake of Wheat and subsequent Maize crop. Pure and Applied Biology. Vol. 4, Issue 4, 2015, \\ pp 471-479. http://dx.doi.org/10.19045/bspab.2015.44004
}

Received: $19 / 05 / 2015$

Revised: 05/11/2015

Accepted: $15 / 11 / 2015$

\section{Abstract}

The use of city waste as compost can provide a two way benefits of increasing soil productivity along with preventing pollution associated with population pressure, industrialization and urbanization. This study was conducted to determine the effect of the compost applied with chemical fertilizer, its effect on NPK uptake and nutrient use efficiency by wheat and maize plant. In this context, the effect of city waste compost at 10 and 20 tone ha- 1 was evaluated along the application of half and $3 / 4$ of the recommended NPK doses on wheat crop and their residual effect on maize crop. The experimental design was RCBD with 3 replication for both crops under the same layout at Pirsabak Research Institute, Nowshehra. Commerical compost was applied and mixed with the soil a month prior to sowing. The phosphatic and potash fertilizer are applied in the form of SSP and SOP at time of sowing while the N fertilizer are applied in three split doses half at sowing time while the remaining with the first and second irrigation. In the succeeding reason, maize was sown in the same layout without applying any compost and chemical fertilizers to evaluate the residual effect of previously applied fertilizers. The CWC significantly improved both the wheat and residual maize thousand grain weight, grain yield and biological yield over alone NPK with maximum values for 20 t CWC ha- 1 with $75 \%$ NPK. The CWC also promoted the NPK status of soil and their uptake by wheat and residual maize suggesting that integration of CWC with NPK could improve the nutrient use efficiency and save the use of chemical fertilizer 25 to $50 \%$. The higher yield and superior performance of CWC in conjunction with NPK over sole NPK or control even in the residual maize advocated that the 
use of CWC could help in maintaining the soil productivity for the long run. These results suggested that the use of CWC will not only promote the agricultural productivity but could also help in safe disposal of the city wastes and could manage the current pollution scenario with increasing population pressure in urban areas of the country. Based the present study the application of 20 tha-1 CWC with $75 \%$ NPK could maintain higher yields of wheat and maize for two seasons under prevailing soil and climatic conditions. However, for wide spread application the CWC must be checked for contaminants like heavy metals and pathogens for safe handling and disposals to soils and preventing any hazardous effects on soil plant environment.

Keywords: City waste compost; Urea; Single super phosphate; Sulphate of potash; Wheat; Maize.

\section{Introduction}

The use of compost is beneficial because at one side it is a good source of nutrient while at other side it improve the organic content of the soil which leads to improve biological activity in the soil system. Enhanced organic matter content of the soil because compost is full of nutrients and contain sufficient amount of nutrients and organic matter. The application of compost enhanced the soil physical and chemical properties and hence the crop yield also increased. Compost is the need of our soil. The physical conditions such as water permeability, voidratio, porosity, bulk density and hydraulic conductivity (water movement in soil) were significantly affected when farm yard manure at the $10 \mathrm{t} \mathrm{ha}^{-1}$ was applied along with commercial fertilizers, shows that FYM can improve the physical condition of sodic soil and can enhance the wheat and rice yields [1]. While on the other hand, the application of commercial fertilizers are expensive as well as unsafe for environment. Due to rapid urbanization and uncontrolled growth rate of pollution, municipal solid waste management (MSWM) has become acute problem. Various research conducted on the (MSW) shows that about 90\% of MSW is not dumped and diposed off properly which causes problem to health as well as environment. [2]. The use of MSW is increasing day by day in agriculture as a soil conditioner and organic fertilizer. This practice (MSW) is an important tool for recycling and dumping of the solid wastes.
In agriculture these compost are widely used for crop nutrient as well as soil conditioner. Using the residues of human consumption, agricultural activities, municipal garbage, plants and animals can enhance physiochemical condition of the soil and also improve the nutrientioal status and productivity of the soil [3]. The use of MSW in Agriculture is beneficial because at one side it provide essential nutrient for the proper plant while at other side it improve soil physio-chemical properties and cost effective[4]. Keeping in view the importance of fertilizer formulations in nutrient availability, a research project was planned to study the effect of NPK fertilizers and compost on wheat and residual maize plant growth. Main objective of the research was to determine the effect of the compost applied with chemical fertilizer on yield and yield component of wheat and subsequent maize as residual effect, to determine the effect of compost on NPK content of soil as indicator of soil fertility status and the effect of the compost on nutrient uptake and use efficiency by determing the NPK uptake by wheat and maize plant.

\section{Materials and Methods}

The effect of city waste compost (CWC) applied alone and in combination with chemical fertilizers on the yield and nutrient uptake of wheat and succeeding maize was studied at Research Institute (CCRI) Pirsabak during rabi 2011-12. There were nine treatments such as Control (No NPK or compost), full recommended NPK (120:90:60 kg N:P $\mathrm{P}_{5}: \mathrm{K}_{2} \mathrm{O} \mathrm{ha}^{-1}$ ), $\quad 75 \%$ of 
recommended NPK + Compost @ 20 t ha ${ }^{-1}$, $50 \%$ of recommended NPK + Compost @ $20 \mathrm{t} \mathrm{ha}^{-1}, 75 \%$ of recommended NPK + Compost @ 10 t ha $^{-1}$ and $50 \%$ of recommended NPK + Compost @ $10 \mathrm{t} \mathrm{ha}^{-1}$. The experiment was conducted in randomized complete block design with three replications for both crops under the same layout. A plot size of $4 \mathrm{~m} \mathrm{x} 2.4 \mathrm{~m}$ was used, each plot consisting of 8 rows, $4 \mathrm{~m}$ long and $30 \mathrm{~cm}$ apart for wheat crop and 4 rows for maize with $60 \mathrm{~cm}$ distance from each other. Wheat variety "Attahabib" was used with a seed rate of $100 \mathrm{~kg} \mathrm{ha}^{-1}$ in the first season followed by maize crop variety Azam with recommended dose of NPK (120: 90: $60 \mathrm{~kg} \mathrm{~N}: \mathrm{P}_{2} \mathrm{O}_{5}: \mathrm{K}_{2} \mathrm{O} \mathrm{ha}^{-1}$ ) through urea, single super phosphate (SSP) and sulfate of potash (SOP), respectively. Commercial city waste compost was applied and mixed with the soil a month prior to sowing. All of the SSP and SOP was applied at the time of sowing while half of the urea was applied at the time of sowing and remaining with the first and second irrigation. In the succeeding reason, maizecultivors was sown in the same layout without applying any compost and chemical fertilizers to evaluate the residual effect of presiously applied fertilizers. Wheat and maize leaves were collected for nutrient uptake. Similarly, soil samples after each harvest were collected to evaluate the effected of applied compost on soil fertility status.

\section{Field data}

The data was recorded on 1000 grain weight, bio yield $\left(\mathrm{kg} \mathrm{ha}^{-1}\right)$, grain yield $(\mathrm{kg}$ $\mathrm{ha}^{-1}$ ) and harvest index.

\section{Laboratory analysis}

Total $\mathrm{N}$ in soil and plant was determined through the procedure of of Bremner and Mulvaney [5] through Kjeldahal appratrus. AB-DTPA extractable $P$ and $K$ was measured in the soil by the method of Soltonpour and Schwab [6].

\section{Leaf Analysis}

The total $\mathrm{P}$ and $\mathrm{K}$ in the leaf samples were measure after digesting these samples in mixture of $\mathrm{HNO}_{3}$ and $\mathrm{HCLO}_{4}$ as suggested by Benton et al [7]. The total uptake in the plants both in wheat and maize were determine though multiplication of concentrations with respective biomass of the plant.

\section{Statistical analysis}

The statistical analysis of data was carried out by the method of Steel and Toorie [8] using M Stat C package. LSD test was applied for means separation between the treatments.

\section{Results and Discussion}

The physic-chemical properties of experimental soil showed that the soil was sandy loam in texture and low in organic matter $(0.34 \%)$ while before treatment application the nitrogen $(0.017 \%)$ and phosphorus $\left(4.2 \mathrm{mg} \mathrm{kg}^{-1}\right)$ concentration were also low for the proper plant growth. Furthermore, the soil was alkaline in reaction and calcareous in nature due to high lime content $(14.3 \%)$. The results showed that the potassium concentration was 6.7 $\mathrm{mg} \mathrm{g}^{-1}(0.67 \%)$ phosphorus concentration was $0.54 \mathrm{mg} \mathrm{g}^{-1}(0.054 \%)$ and the total nitrogen was $1.91 \mathrm{mg} \mathrm{g}^{-1}(0.19 \%)$ (Table 1$)$. The organic matter was $10 \%$ and $\mathrm{pH}$ of the sample was 8.3. The results indicated that this compost if applied at the rate of $20 \mathrm{t} \mathrm{ha}^{-1}$ can supply $134 \mathrm{~kg} \mathrm{~K}, 10.0 \mathrm{~kg} \mathrm{P}$ and $38.0 \mathrm{~kg}$ $\mathrm{N} \mathrm{ha}^{-1}$ to the crop (Table 2). 
Table 1. Physico-chemical properties of experimental soil

\begin{tabular}{llcc}
\hline S. NO. & Property & Unit & Value \\
\hline 1 & Total nitrogen & $\%$ & 0.017 \\
2 & AB-DTPA extractable P & $\mathrm{mg} \mathrm{kg}^{-1}$ & 4.2 \\
3 & AB-DTPA extractable K & $\mathrm{mg} \mathrm{kg}^{-1}$ & 90 \\
4 & $\mathrm{pH}(1: 5)$ & & 8.3 \\
5 & EC $(1: 5)$ & $\mathrm{d} \mathrm{S} \mathrm{m}^{-1}$ & 0.08 \\
6 & Organic matter & $\%$ & 0.34 \\
7 & Lime $\left(\mathrm{CaCO}_{3}\right)$ & $\%$ & 14.3 \\
8 & Clay & $\%$ & 12.2 \\
9 & Silt & & 50 \\
10 & Sand & -- & 37.8 \\
11 & Textural class & -1 & Sandy loam \\
\hline
\end{tabular}

Table 2. Composition of commercial city waste compost used for the study

\begin{tabular}{lcc}
\hline Parameter & Unit & Value \\
\hline $\mathrm{pH}$ & & 8.3 \\
Organic matter & $\%$ & 10 \\
Total N & $\%$ & 0.19 \\
Total K & $\%$ & 0.67 \\
Total P & $\%$ & 0.054 \\
\hline
\end{tabular}

Yield and yield components of wheat and maize

Data on 1000 grain weight of wheat and subsequent maize as influenced by city waste compost and NPK fertilizer at different rations are presented in Table 3. The non-significant differences among treatments of wheat suggested that any of the combination of CWC with NPK is sufficient for production of yield. The difference between NPK and any ratio of integrated used of CWC+NPK is very low and indicated saving of chemical fertilizers. In succeeding maize crop the performance of $20 \mathrm{t} \mathrm{ha}^{-1} \mathrm{CWC}$ applied with 50\% NPK produced high yield as compared to full dose and control. CWC at 20 t ha-1 along with 50\% NPK produced 320.67 which was $9.4 \%$ and $45 \%$ higher than full dose NPK and control respectively suggesting that
CWC was superior in performance (Table $3)$. The higher performance of CWC with residual maize is due to the slow release of nutrients from $\mathrm{CWC}$ which was a good sign for improvement in soil phsico-chemical properties for a long time. Similar results were obtained by the Lilly white et al [9] who found that application of the municipal waste derived compost resulted in greater 1000 grain weight in the first season.

Full dose of NPK (120:90:60 kg $\mathrm{N}: \mathrm{P} 2 \mathrm{O} 5: \mathrm{K} 2 \mathrm{O} \mathrm{ha}^{-1}$ ) and $20 \mathrm{tha}^{-1} \mathrm{CWC}$ with 75\% NPK (90:60:45 kg N:P2O5:K205) produced almost similar biological yields of 7.70 and $7.07 \mathrm{t} \mathrm{ha}^{-1}$ respectively during the first crop indicating that the NPK application is saved with CWC. Beside this all the treatments which is fertilized either with 50 or $75 \%$ NPK with CWC is statistically same. These value suggesting that the CCWC is applied with 50 or $75 \%$ 
NPK is as good for yield production of first season (Table 3 ). In the succeeding maize crop, the performance of CWC applied with either 75 or $50 \%$ was better than control and full dose of NPK suggesting that CWC could maintain the soil productivity in the long run. CWC applied at $20 \mathrm{t} \mathrm{ha}^{-1}$ along with $75 \%$ NPK produced $6.49 \mathrm{t} \mathrm{ha}^{-1}$ maize which was 30.3 and $24.3 \%$ higher than control and full dose of NPK (Fig. 3). respectively. But CWC with 50 or $75 \%$ NPK produced slightly higher yield than full dose of NPK advocating the excellent performance in the long run (Table 3).

During first season, the full dose of NPK (120:90:60 kg N:P $\mathrm{P}_{2} \mathrm{O}_{5}: \mathrm{K}_{2} \mathrm{O} \mathrm{ha}^{-1}$ ) and $20 \mathrm{t}$ CWC with $75 \%$ NPK (90:60:45 kg $\mathrm{N}: \mathrm{P} 2 \mathrm{O}: \mathrm{K} 2 \mathrm{O} \mathrm{ha}^{-1}$ ) produced almost similar grain yields of 4.59 and $4.30 \mathrm{t} \mathrm{ha}^{-1}$, respectively suggesting that NPK could be saved with application of CWC. However, with further decrease in NPK the grain yield drastically reduced to $3.41 \mathrm{t} \mathrm{ha}^{-1}$. Similarly, reducing the city waste compost (CWC) from 20 to 10 still with $75 \%$ NPK it did not produced grain yields comparable to full NPK alone (Table 3). These values revealed that in the first season, the possible optimum dose of CWC and NPK could be $20 \mathrm{t} \mathrm{ha}^{-}$ ${ }^{1}+75 \%$ NPK for wheat crop. In the succeeding maize crop, the performance of CWC either applied with 75 or $50 \%$ was better than control and full dose of NPK. CWC plus $75 \%$ NPK produced $4.43 \mathrm{t} \mathrm{ha}^{-1}$ maize which was 73.7 and $40.6 \%$ higher than control and full NPK, respectively. Even CWC with 50\% NPK produced slightly higher yield than full dose of NPK advocating the superior performance of CWC in the long run. The higher performance of CWC in the residual maize could be associated to it slower release of nutrients and long lasting beneficially changes in the soil physico-chemical properties brought about by organic sources. Similar results were found by the Rostami et al. [10] who obtained maximum biomass with the combination of NPK and city waste compost in soya been.

Table 3. 1000 grain weight, biological and grain yield of wheat and succeeding maize as influenced by the given ratio of city waste compost (CWC) and chemical NPK fertilizers.

\begin{tabular}{|c|c|c|c|c|c|c|c|}
\hline \multicolumn{2}{|l|}{ Treatments } & Wheat & Maize & Wheat & Maize & Wheat & Maize \\
\hline $\operatorname{CWC}\left(\mathrm{t} \mathrm{ha}^{-1}\right)$ & NPK $\left(\mathrm{kg} \mathrm{ha}^{-1}\right)$ & \multicolumn{2}{|c|}{1000 grain weight $(\mathrm{g})$} & \multicolumn{2}{|c|}{ Biological yield (t ha-1) } & \multicolumn{2}{|c|}{ Grain yield ( $t$ ha-1) } \\
\hline 0 & 0 & $36 c$ & $220.67 \mathrm{c}$ & $4.90 \mathrm{e}$ & $4.98 \mathrm{c}$ & $2.73 \mathrm{~d}$ & $2.55 \mathrm{e}$ \\
\hline 0 & 120:90:60 & $50 \mathrm{a}$ & $293.00 \mathrm{~b}$ & $7.70 \mathrm{a}$ & $5.22 b c$ & $4.59 \mathrm{a}$ & $3.15 \mathrm{~d}$ \\
\hline 20 & $90: 60: 45$ & $48 \mathrm{ab}$ & $255.33 \mathrm{e}$ & 7.07ab & $6.49 \mathrm{a}$ & $4.30 \mathrm{a}$ & $4.43 \mathrm{a}$ \\
\hline 20 & $60: 45: 30$ & $47 \mathrm{ab}$ & $320.67 \mathrm{a}$ & $6.55 \mathrm{~cd}$ & $5.52 b$ & $3.41 \mathrm{bc}$ & $4.12 b$ \\
\hline 10 & $90: 60: 45$ & $47 \mathrm{ab}$ & $266.70 \mathrm{~d}$ & $6.82 b c$ & $5.34 \mathrm{~b}$ & $3.66 \mathrm{~b}$ & $3.41 \mathrm{c}$ \\
\hline 10 & $60: 45: 30$ & $45 b$ & $279.30 \mathrm{c}$ & $6.11 \mathrm{~d}$ & $5.23 b c$ & $3.17 \mathrm{c}$ & $3.27 \mathrm{~cd}$ \\
\hline $\operatorname{LSD}(5 \%)$ & & 5.136 & 3.592 & 0.418 & 0.418 & 0.36 & 0.203 \\
\hline
\end{tabular}

Post-harvest soil NPK concentration of wheat and succeeding maize

The results showed that higher post-harvest soil $\mathrm{N}(0.027 \%)$ was observed in the treatment fertilized with $75 \%$ recommended $\mathrm{NPK}+\mathrm{CWC}$ applied at $20 \mathrm{t} \mathrm{ha}^{-1}$ followed by $(0.026 \%)$ in the treatment receiving full recommended NPK in wheat crop. In succeeding maize, the post-harvest soil concentration $(0.22 \%)$ in the treatment which is fertilized by $3 / 4$ of recommended $\mathrm{NPK}+$ Compost at $20 \mathrm{t} \mathrm{ha}^{-1}$ followed by 
$(0.21 \%)$ in the treatment receiving 50 recommended NPK along with compost $20 \mathrm{t}$ ha $^{-1}$ while minimum post-harvest soil $\mathrm{N}$ (0.012)was measured in control treatment (Table 4). Majumdar et al [11] observed that the application of organic materials such as farmyard manure with combination of rock phosphate enhanced soil $\mathrm{N}$ content. The higher $\mathrm{N}$ in NPK alone plots could be attributed to plant root biomass. The results of post-harvest soil $\mathrm{P}$ concentration revealed that combinations of NPK and city waste compost influenced $\mathrm{P}$ concentration significantly. The higher phosphorus concentration of $3.51 \mathrm{mg} \mathrm{kg}^{-1}$ was recorded in treatment which is fertilized by full recommended NPK followed by a plot which received $3 / 4$ of recommended NPK along compost $20 \mathrm{t} \mathrm{ha}^{-1}$ upon which wheat crop was grown (Table 4). In maize crop The higher phosphorus concentration of $3.75 \mathrm{mg} \mathrm{kg}^{-1}$ was recorded in treatment where combination of $3 / 4$ of recommended $\mathrm{NPK}+$ Compost @ $20 \mathrm{t} \mathrm{ha}^{-1}$ was applied followed by value $3.23 \mathrm{mg} \mathrm{kg}^{-1}$ recorded in a plot which received full recommended NPK while minimum $\mathrm{P}$ concentration $2.01 \mathrm{mg} \mathrm{kg}^{-1}$ was observed in control treatment.

Table 4. Post-harvest soil total $N(\%)$ concentrations of wheat and succeeding maize as influenced by the given ratio of city waste compost (CWC) and chemical NPK fertilizers.

\begin{tabular}{lccccccc}
\hline \multicolumn{1}{c}{ Treatments } & \multicolumn{2}{c}{ Wheat } & Maize & Wheat & Maize & Wheat & Maize \\
\hline CWC $\left(\mathrm{t} \mathrm{ha}^{-1}\right)$ & $\mathrm{NPK}\left(\mathrm{kg} \mathrm{ha}^{-1}\right)$ & \multicolumn{2}{c}{$\mathrm{N}(\%)$} & \multicolumn{2}{c}{$\mathrm{P}\left(\mathrm{mg} \mathrm{kg}^{-1}\right)$} & \multicolumn{2}{c}{${\mathrm{K}\left(\mathrm{mg} \mathrm{kg}^{-1}\right)}^{2}$} \\
\hline 0 & 0 & $0.015 \mathrm{c}$ & $0.012 \mathrm{c}$ & $2.43 \mathrm{~b}$ & $2.01 \mathrm{~cd}$ & $110 \mathrm{~d}$ & $102 \mathrm{~d}$ \\
0 & $120: 90: 60$ & $0.026 \mathrm{a}$ & $0.019 \mathrm{ab}$ & $3.51 \mathrm{a}$ & $3.23 \mathrm{~b}$ & $150 \mathrm{a}$ & $114 \mathrm{~b}$ \\
20 & $90: 60: 45$ & $0.027 \mathrm{a}$ & $0.022 \mathrm{a}$ & $3.19 \mathrm{a}$ & $3.75 \mathrm{a}$ & $140 \mathrm{bc}$ & $119 \mathrm{a}$ \\
20 & $60: 45: 30$ & $0.022 \mathrm{ab}$ & $0.021 \mathrm{a}$ & $2.60 \mathrm{~b}$ & $2.15 \mathrm{~cd}$ & $140 \mathrm{bc}$ & $106 \mathrm{c}$ \\
10 & $90: 60: 45$ & $0.019 \mathrm{~b}$ & $0.018 \mathrm{ab}$ & $2.70 \mathrm{~b}$ & $2.40 \mathrm{c}$ & $145 \mathrm{ab}$ & $111 \mathrm{~b}$ \\
10 & $60: 45: 30$ & $0.016 \mathrm{c}$ & $0.016 \mathrm{bc}$ & $2.57 \mathrm{~b}$ & $1.85 \mathrm{~d}$ & $135 \mathrm{c}$ & $105 \mathrm{~cd}$ \\
\hline LSD (5\%) & & 0.005 & 0.023 & 0.397 & 0.432 & 9.033 & 3.859 \\
\hline
\end{tabular}

\section{Plant NPK concentrations of wheat and maize}

In first season the plots which received full dose of NPK (120:90:60 kg N:P2O5:K205 $\mathrm{ha}^{-1}$ ), CWC @ $20 \mathrm{t} \mathrm{ha}^{-1}$ along 75\% NPK (90:60;45 kg N:P2O5:K2O ha ${ }^{-1}$ ) increased the $\mathrm{N}$ content in leaf as 1.124 and 1.048 respectively, indicating that the NPK is enough to enhanced $\mathrm{N}$ concentration in wheat leaf and also CWC with $75 \%$ NPK. But after reducing the NPK to $50 \%$ the $\mathrm{N}$ concentration is also reduced (Table 5). Thus the data indicates that the NPK is a good source to increased $\mathrm{N}$ content. In succeeding maize crop the performance of CWC applied with $75 \%$ NPK was better over full dose of
NPK and control. The concentration of $\mathrm{N}$ in a plot which received CWC with $75 \%$ NPK was 1.216 which is slightly higher the than full dose of NPK. However when NPK is reduced to $50 \%$ the concentration of $\mathrm{N}$ in maize leaf also decreases. Still the full dose of NPK did not increase the concentration as compared to $20 \mathrm{t} \mathrm{ha}^{-1} \mathrm{CWC}$ along with $75 \%$ NPK. This shows that the CWC is a better source to increase $\mathrm{N}$ content because off slow release of nutrients. The similar results were presented by Awaad et al [12] reported that the combined application of organic materials with rock phosphate increased the nitrogen concentration in plant. The maximum $\mathrm{P}$ content was recorded in a wheat plot which received full dose of NPK 
$0.258 \%$ followed by CWC PLUS 75\% NPK0.237\%.But when there is decrease in NPK to 75 to $50 \%$ so the decrease is also recorded in Phosphorus concentration suggesting that NPK is a better source to increased $\mathrm{P}$ concentration. In succeeding maize crop the performance of city waste compost plus $75 \%$ NPK significantly increased Phosphorus concentration in maize leaf over full dose of NPK and control which was 9.2 and $70 \%$ high respectively (Table 5). Similar results were showed by Akande et al. [13] observed the mixed application of cow dung and poultry manure with phosphatic fertilizers enhanced phosphorus concentration in plant.

Table 5. Pant $\mathrm{N}$ concentrations $(\%)$ of wheat and succeeding maize as influenced by the given ratio of city waste compost (CWC) and chemical NPK fertilizers

\begin{tabular}{|c|c|c|c|c|c|c|c|}
\hline Treatments & & Wheat & Maize & Wheat & Maize & Wheat & Maize \\
\hline $\operatorname{CWC}\left(\mathrm{tha}^{-1}\right)$ & NPK $\left(\mathrm{kg} \mathrm{ha}^{-1}\right)$ & \multicolumn{2}{|c|}{--------_\%--------- } & \multicolumn{2}{|c|}{------------\%---------- } & \multicolumn{2}{|c|}{-------------\% --------- } \\
\hline 0 & 0 & $0.076 \mathrm{c}$ & $0.686 c$ & $0.190 \mathrm{~d}$ & $0.201 \mathrm{e}$ & $2.03 b$ & $2.29 \mathrm{e}$ \\
\hline 0 & 120:90:60 & $1.124 \mathrm{a}$ & $1.078 \mathrm{ab}$ & $0.258 \mathrm{a}$ & $0.313 \mathrm{~b}$ & $3.43 \mathrm{a}$ & $3.90 \mathrm{a}$ \\
\hline 20 & $90: 60: 45$ & $1.048 \mathrm{ab}$ & $1.216 \mathrm{a}$ & $0.237 \mathrm{ab}$ & $0.342 \mathrm{a}$ & $3.31 \mathrm{a}$ & $3.75 \mathrm{ab}$ \\
\hline 20 & $60: 45: 30$ & $0.892 \mathrm{bc}$ & $0.924 \mathrm{abc}$ & $0.213 \mathrm{~b} \mathrm{~cd}$ & $0.294 \mathrm{bc}$ & $3.22 \mathrm{a}$ & $3.29 \mathrm{~cd}$ \\
\hline 10 & $90: 60: 45$ & $0.924 a b c$ & $0.0857 b c$ & $0.226 \mathrm{bc}$ & $0.276 \mathrm{c}$ & $3.19 \mathrm{a}$ & $3.51 \mathrm{bc}$ \\
\hline 10 & $60: 45: 30$ & $0.844 \mathrm{bc}$ & $0.736 b c$ & $0.206 \mathrm{~cd}$ & $0.227 \mathrm{~d}$ & $3.01 \mathrm{a}$ & $3.25 \mathrm{~d}$ \\
\hline $\operatorname{LSD}(5 \%)$ & & 0.2138 & 0.3456 & 0.0284 & 0.0215 & 0.4242 & 0.2505 \\
\hline
\end{tabular}

NPK uptake of wheat and succeeding maize

Data revealed that Nitrogen uptake of both wheat crop and succeeding residual maize is significantly improved over control by the application of CWC applied with different ratios of NPK. The higher $\mathrm{N}$ uptake was recorded in plot which received full dose of NPK $51.6 \mathrm{~kg} \mathrm{ha}^{-1}$ followed by CWC plus $75 \%$ NPK $45 \mathrm{~kg} \mathrm{ha}^{-1}$. After reducing the NPK to $50 \%$ and CWC to $10 \mathrm{t} \mathrm{ha}^{-1}$ the uptake of nitrogen is also reduces to $26.7 \mathrm{~kg}$ $\mathrm{ha}^{-1}$ (Table 6). These value indicating that the possible dose of NPK and CWC plus $75 \%$ NPK for wheat. The N uptake of CWC plus $75 \%$ NPK is $53.8 \mathrm{~kg} \mathrm{ha}^{-1}$ which was 194.8 and $31.5 \%$ high as compared to control and full dose of NPK, respectively in maize crop. .Even the uptake of $\mathrm{CWC}$ with $50 \% \mathrm{NPK}$ is slightly higher than full dose of NPK showing the good performance of $\mathrm{CWC}$ for a long run. The higher $\mathrm{N}$ uptake is related to the slow release of nutrients from compost. Similar results were found by
Awaad et al. [12] who observed that the mixed application of rock phosphate as a source of phosphate fertilizers with organic materials increased $\mathrm{N}$ uptake of plant. The $\mathrm{P}$ uptake of wheat crop was quiet similar in full dose of NPK and $20 \mathrm{t} \mathrm{ha}^{-1}$ CWC with $75 \%$ NPK that is 11.8 and $10.1 \mathrm{~kg} \mathrm{ha}^{-1}$, respectively but there is no such a great change recorded when the NPK is reduced to 75 and $50 \%$ and cwc is reduced to $10 \mathrm{t} \mathrm{ha}^{-}$ ${ }^{1}$ (Table 6). So the study suggesting that the full dose of NPK is applied or CWC plus 75 or $50 \%$ is applied to wheat is sufficient for $\mathrm{P}$ uptake. The $\mathrm{P}$ uptake of maize in the plot treated with CWC along with 50 or $75 \%$ NPK were 15.1 and $12.2 \mathrm{~kg} \mathrm{ha}^{-1}$ respectively which was 52.5 and $23.2 \%$ high over full dose of NPK .It shows the superior efficacy of CWC along with 50 or $75 \%$ NPK for plant nutrient uptake of a crop. Samilir results were found by Eradal et al. [14] who presented that the combined application of organic fertilizers with chemical fertilizers enhanced the phosphorus concentration in 
plants. The maximum $\mathrm{K}$ uptake of $157.4 \mathrm{~kg}$ $\mathrm{ha}^{-1}$ was recorded in wheat plot which received full dose of NPK which was $184 \%$ high over control. The Table 6 shows that CWC is either applied with $50 \%$ or $75 \%$ NPK is suitable for K uptake and also for yield production but here the full dose of NPK is saved and superior for nutrients uptake of plants. In succeeding residual maize crop the $\mathrm{K}$ uptake is higher either the plot received 50 or $75 \%$ NPK with CWC over control and full dose of NPK (Table 6). The higher Potassium concentration of 150 $\mathrm{mg} \mathrm{kg}^{-1}$ was recorded in a treatment where combination of $3 / 4$ of recommended NPK and Compost @ $20 \mathrm{t} \mathrm{ha}^{-1}$ followed by a treatment receiving $3 / 4$ of recommended NPK along compost $10 \mathrm{t} \mathrm{ha}{ }^{-1} 145 \mathrm{mg} \mathrm{kg}^{-1}$ upon which wheat crop was grown (Table 6).In succeeding maize crop the higher Potassium concentration of $119 \mathrm{mg} \mathrm{kg}^{-1}$ was recorded in treatments where combination of $3 / 4$ of recommended NPK and Compost @ $20 \mathrm{t} \mathrm{ha}^{-}$ ${ }^{1}$ was applied followed by $114 \mathrm{mg} \mathrm{kg}^{-1}$ in the treatment receiving full recommended dose of NPK. Toor and Bishnai [15] showed the similar results and observed the effect of combined application of poultry manure (pm), farmyard manure (FYM) and urea in maize-wheat rotation on plant nutrition and determine that PM and FYM were equally effective for K availability.

Table 6. NPK uptake of wheat and succeeding maize as influenced by the given ratio of city waste compost (CWC) and chemical NPK fertilizers

\begin{tabular}{|c|c|c|c|c|c|c|c|}
\hline \multirow{2}{*}{$\begin{array}{l}\text { Treatments } \\
\text { CWC }\left(\mathrm{t} \mathrm{ha}^{-1}\right)\end{array}$} & \multirow{2}{*}{ NPK $\left(\mathrm{kg} \mathrm{ha}^{-1}\right)$} & Wheat & Maize & Wheat & Maize & Wheat & Maize \\
\hline & & \multicolumn{2}{|c|}{$\mathrm{kg} \mathrm{ha}^{-1}$} & \multicolumn{2}{|c|}{$\mathrm{kg} \mathrm{ha}^{-1}$} & \multicolumn{2}{|c|}{$\mathrm{kg} \mathrm{ha}^{-1}$} \\
\hline 0 & 0 & $20.7 \mathrm{f}$ & $17.5 \mathrm{f}$ & $5.1 \mathrm{e}$ & $5.1 \mathrm{e}$ & $55.4 \mathrm{f}$ & $58.4 \mathrm{f}$ \\
\hline 0 & 120:90:60 & $51.6 \mathrm{a}$ & $33.9 \mathrm{c}$ & $11.8 \mathrm{a}$ & $9.9 \mathrm{c}$ & $157.4 \mathrm{a}$ & $122 \mathrm{c}$ \\
\hline 20 & $90: 60: 45$ & $45.0 \mathrm{~b}$ & $53.8 \mathrm{a}$ & $10.1 \mathrm{~b}$ & $15.1 \mathrm{a}$ & $142.3 b$ & $166 \mathrm{a}$ \\
\hline 20 & $60: 45: 30$ & $30.4 d$ & $40.9 b$ & $7.2 \mathrm{~cd}$ & $12.2 b$ & $109.8 \mathrm{~d}$ & $135.5 b$ \\
\hline 10 & $90: 60: 45$ & $33.8 \mathrm{c}$ & $29.2 d$ & $8.2 \mathrm{de}$ & $9.4 \mathrm{c}$ & $116.7 \mathrm{c}$ & $119.6 \mathrm{~d}$ \\
\hline 10 & $60: 45: 30$ & $26.7 \mathrm{e}$ & $24.0 \mathrm{e}$ & $6.4 \mathrm{e}$ & $7.5 \mathrm{~d}$ & $95.4 \mathrm{e}$ & $106.3 \mathrm{e}$ \\
\hline LSD (5\%) & & 2.391 & 1.6446 & 1.5796 & 0.8984 & 0.6869 & 1.8853 \\
\hline
\end{tabular}

\section{Conclusions}

The higher thousand grain weight, grain yield and biological yield of wheat crop in city waste composte (CWC) treated soils showed that the city waste compost could be successfully used as substitute for other organic fertilizers. Application of $20 \mathrm{t} \mathrm{ha}^{-1}$ CWC with $75 \%$ NPK could maintain higher yields of wheat and maize for two seasons under prevailing soil and climatic conditions. The CWC also promoted the NPK status of soil and their uptake by wheat and residual maize suggesting that integration of CWC with NPK could improve the nutrient use efficiency and save the use of chemical fertilizer 25 to $50 \%$. These results suggested that the use of CWC will not only promote the agricultural productivity but could also help in safe disposal of the city wastes and could manage the current pollution scenario with increasing population pressure in urban areas of the country.

Authors' contributions

Conceived and designed the experiments: $\mathrm{M}$ Mussarat. Performed the experiments: $\mathrm{T}$ 
Naseem, MA Khan \& M Waheed. Analyzed the data: SN Khan. Contributed

reagents/materials/analysis tools: $\mathrm{M}$ Adil, $\mathrm{T}$

Kamal \& T Naseem. Wrote the paper: MA

Khan \& T Naseem.

\section{References}

1. Hussain NG, Arshadullah M \& Mujeeb F. 2001. Evaluation of amendments for the improvement of physical properties of sodic soil. Int. J. Agric. Biol. 3: 319-322.

2. Sharholy M, Ahmad K, Mahmood G \& Trivedi RC. 2008. Municipal solid waste management in Indian cities - A review. Waste Management 28(2): 459-467.

3. Sposito GL, Lund $\mathrm{J} \&$ Chang AC. 1982. Trace metal chemistry in arid-zone field soils amended with sewage sludge: fractionation of $\mathrm{Ni}, \mathrm{Cu}, \mathrm{Zn}, \mathrm{Cd}$. and $\mathrm{Pb}$ in solid phases. Soil Sci. Soc. Am. J. 46: 260-264.

4. Bundela PS, Gautam SP, Pandy MK, Awashtiand \& Sarsaiya S. 2010. Muincipal solid waste management in Indian cities. A review. Int. J Enivn. Sci. 1(4): 591-606.

5. Bremner JM \& Mulvaney CS. 1982. Kjeldhal Method. In method of soil analysis part-2: Chemical \& microbiological properties. Amer. Soc. Argon. Madison, WI. 903-948.

6. Soltanpour PN \& Schwab AP. 1977. A new soil test for simultaneous extraction of macro and micro-nutrients in alkaline soils. Comm. Soil Sci. and Plant Anal. 8: 195-207.

7. Benton J, Wolf JB \& Mills HA. 1991. Plant Analysis Hand Book. A practical sampling, preparation, analysis and interpretation guide. Micro-Macro Publishing Inc., USA.

8. Steel RGD \& Torrie JH. 1980. Principal and Procedures of Statistic. A biometrical approach. McGraw-Hill, New York.

9. Lillywhite R D, Dimambro M E \& Rahn C. 2009. Effectof five municipal waste derived composts on a cereal crop. Compost Science \& Utilization 17(3): 173-179.

10. Rostami SV, pirdashti H, Bahmanyar MA \& Motaghian A (2012). Response of soybean (Glycine max L.) yield and nutrient uptake three consecutive years application of municipal solid waste compost. International J. of Agric. And Crop Sci. 8(4):468-473.

11. Majumdar B, Venkatesh, Kumar MS \& Patiram K (2007). Effect of rock phosphate, superphosphate and their mixtures with FYM on soyabeen and soil-P pools in a typichapludalf of Megalaya. Journal of the Indian society of soil science 55(2): 167-174.

12. Awaad MS, Rashid AA \& Bayoumi MA (2009).Effect of farmyard manure combined with some phosphate sources on the productivity of canola plants grown on a sandy soil. Research $J$. ofAgric. And Biol. Sci. 5: 1176-1181

13. Akande MO, Oluwatoyinbo FI, Kayode CO \& Olowokere FA (2006). Response of Maize (Zea mays) and Okra (Abelmoschusesculentus) Intercrop Relayed with Cowpea (Vignaunguiculata) to Different Levels of Cow Dung Amended Phosphate Rock World. Journal of Agricultural Sciences 2(1): 119-122.

14. Eradal I, Bozkart MA, Cimrin KM, Karaca S \& Salgam M (2000). Effects of humic acid and phosphorus fertilizer application on growth phosphorus uptake of maize (zea mays L.) grown on a calcareoussoil. Turkish J. of Agric. and Foresty.24 (6):663-668.

15. Toor AS \& Bishnoi SR (1996). Effect of application of poultry manure and farmyard manure and urea on available nutrient status of soil maize-wheat rotation. Ind. J. Ecol. 23(2): 99-103. 